\title{
Correction to: Climate change adaptation strategies, productivity and sustainable food security in southern Mali
}

\author{
Aboubacar Diallo ${ }^{1} \cdot$ Emmanuel Donkor $^{2}$ (D) Victor Owusu $^{3}$ \\ Published online: 20 July 2021 \\ (C) The Author(s) 2021
}

\section{Correction to: Climatic Change https://doi.org/10.1007/s10584-020-02684-8}

The article Climate change adaptation strategies, productivity and sustainable food security in southern Mali, written by Aboubacar Diallo, Emmanuel Donkor \& Victor Owusu, was originally published Online First without Open Access. After publication in volume 159, issue 3, page 307327] the author decided to opt for Open Choice and to make the article an Open Access publication. Therefore, the copyright of the article has been changed to (C) The Author(s) 2021 and the article is forthwith distributed under the terms of the Creative Commons Attribution.

Funding Open Access funding enabled and organized by Projekt DEAL.

The online version of the original article can be found at https://doi.org/10.1007/s10584-020-02684-8

Aboubacar Diallo

dialloaboubacar44@yahoo.fr

Emmanuel Donkor

edonkor.knust@gmail.com

Victor Owusu

vowusu.agric@knust.edu.gh

1 Kwame Nkrumah University of Science and Technology and Indicated that Rhine-Waal University of Applied Sciences, Bamako, Mali

2 Faculty of Life Sciences, Rhine-Waal University of Applied Sciences, Marie-Curie-Straße 1, 47533 Kleve, Germany

3 Department of Agricultural Economics, Agribusiness and Extension, Kwame Nkrumah University of Science and Technology, PMB, Kumasi, Ghana 
Open Access This article is licensed under a Creative Commons Attribution 4.0 International License, which permits use, sharing, adaptation, distribution and reproduction in any medium or format, as long as you give appropriate credit to the original author(s) and the source, provide a link to the Creative Commons licence, and indicate if changes were made. The images or other third party material in this article are included in the article's Creative Commons licence, unless indicated otherwise in a credit line to the material. If material is not included in the article's Creative Commons licence and your intended use is not permitted by statutory regulation or exceeds the permitted use, you will need to obtain permission directly from the copyright holder. To view a copy of this licence, visit http://creativecommons.org/licenses/by/4.0/.

Publisher's note Springer Nature remains neutral with regard to jurisdictional claims in published maps and institutional affiliations. 